\title{
Prevalence and determinants of Instrumental Activities of Daily Living (IADL) disability among community- dwelling elderly in a semi-urban setting in Peninsular Malaysia
}

\author{
Muhammad Faizal bin Murat, Zuriati binti Ibrahim", Siti Nur 'Asyura binti \\ Adznam \& Chan Yoke Mun
}

Department of Nutrition and Dietetics, Faculty of Medicine and Health Sciences, Universiti Putra Malaysia, 43400 Serdang, Selangor, Malaysia

\begin{abstract}
Introduction: The ability to perform daily living activities among the elderly is important, as physical disability may lead to dependency and various public health implications. This study aimed to determine the prevalence of instrumental activities of daily living (IADL) disability and its association with socio-demographic characteristics, dietary intake, social participation, perceived-health-status and risk of falls. Methods: This cross-sectional study was conducted among communitybased elderly in the Gombak District of Selangor. 258 respondents aged 60-88 years old (mean age $66 \pm 6.5$ years) were recruited through multi-stage proportional sampling. Most of the respondents (88.4\%) aged 60-74 years and $11.6 \%$ were $\geq 75$ years. IADL disability was determined using an eight-item IADL scale. The presence of IADL disability was defined as needing help in at least one or more of eight-IADL activities. Dietary intake and fall risk were assessed using diet history questionnaire (DHQ) and 21-item fall risk index (FRI-21), respectively. Results: The prevalence of IADL disability among the respondents was $58.1 \%$. A binary logistic regression analyses showed that the following factors predicted IADL disability: advanced age ( $\geq 75$ years, OR=6.4; 95\% CI: 1.3, 30.8), being unmarried $(\mathrm{OR}=2.5 ; 95 \% \mathrm{CI}: 1.1,5.9)$, unemployed/retired $(\mathrm{OR}=2.3 ; 95 \% \mathrm{CI}: 1.2,4.3)$, and at risk of falls $(\mathrm{OR}=2.5 ; 95 \%$ CI: $1.3,6.1$. Conclusion: Predictors such as marriage and employment highlight the importance of social support among elderly. In practical terms, this means that it is incumbent upon caregivers, family members, and the community to provide both physical and emotional support if the functional status of the elderly is to be improved.
\end{abstract}

Keywords: IADL disability, elderly, functional status, Malaysia

\section{INTRODUCTION}

An increase in life expectancy, coupled with a widespread decline in fertility and mortality, has led to a recent rise in the population of the elderly on a global scale. For many developing countries, including Malaysia, this demographic transition is becoming more apparent, although its pattern varies considerably between countries (Bloom, Canning \& Finlay, 2010).

Physical disability is common among the elderly. Developed countries have reported its prevalence ranging 12.0-

\footnotetext{
*Corresponding author: Dr Zuriati Ibrahim

Department of Nutrition and Dietetics, Faculty of Medicine and Health Sciences,

Universiti Putra Malaysia, 43400 Selangor, Malaysia

Tel: 03-89472464; Email: zuriatiib@upm.edu.my

doi: https://doi.org/10.31246/mjn-2018-0142
} 
15.0\% (Ramsay et al., 2008; den Ouden et al., 2013). In contrast, the prevalence rate in developing countries appears to be slightly higher, at 29.0-48.0\% (Chalise, Saito \& Kai, 2008; Malhotra, Chan \& Ostbye, 2010). Malaysia appears to have much higher prevalence of physical disability compared with more developed countries but is still within the range of that of developing countries (Hairi et al., 2010). The elderly are at the greatest risk of becoming dependent, as they suffer difficulties and need assistance to carry out both basic activities of daily living (BADL) and instrumental activities of daily living (IADL). The IADL are key life tasks that seniors must manage to be safe \& independent. They include cleaning and maintaining the house, managing money, moving within the community and preparing meals. IADL disability is defined as experiencing difficulty in carrying out activities that are essential to independent living.

Dependence is the main factor impacting the health and quality of life for the elderly, caregivers, and relatives (Millán-Calenti et al., 2010). The implications of dependency may also lead to an increase in the use of health care services, admission to nursing homes, and hospitalisation (Zisberg et al., 2015). As the number of dependent elderly is predicted to increase, this will impose an enormous and growing economic cost on society.

Much research has been conducted around the world on physical disability among the elderly, but the data from the developed countries may not be applicable to the Malaysian context. Recent studies on the specific IADL disabilities of the Malaysian elderly are limited, with the exception of the work of Momtaz, Hamid \& Ibrahim (2012) and Suzana et al. (2013). The primary objective of this study was, therefore, to determine the prevalence of disability in IADLs among the elderly in a semi- urban setting, in Peninsular Malaysia. This study also aimed to determine the specific factors associated with IADL disability within the study population.

\section{MATERIALS AND METHODS}

\section{Study design and sampling method}

This cross-sectional study was conducted in Mukim Batu, which is one of the sub-districts of Gombak District, in the state of Selangor, in Peninsular Malaysia. Mukim Batu is a semi-urban area situated approximately in the middle of Gombak. A multi-stage proportional sampling method was used for the selection of the study location. The Gombak district was selected as the proportion of the elderly was one of the highest among the other eight districts of Selangor. The Gombak District consists of four sub-districts. The subdistrict of Mukim Batu was selected as it had the highest proportion of elderly compared to the others. All 16 villages in Mukim Batu were selected. The number of respondents recruited from each village was based on the proportion of elderly from each village. Prospective respondents then were identified in each village, from a comprehensive community list of names, of both genders, that was provided by Head of Mukim Batu. They were randomly selected using a 'Research Randomiser' web-based application, sorted according to each village. The community in Mukim Batu was informed about the data collection process through their respective heads of villages. House-to-house visits were made and only the elderly, who had been identified in specific household, were invited to participate in this study.

\section{Participants}

A total of 258 elderly individuals were recruited from June to December 2013 based on the inclusion and exclusion criteria of this study: a person was 
included if they had resided in the study location for $>12$ months, were Malaysian, aged $\geq 60$ years, and able to communicate effectively. Subjects were excluded if they were reported by their family members that they had mental illnesses such as dementia/Alzheimer, terminally ill (end stage cancer/ rehabilitation), bedridden, or suffered hearing difficulties or deafness. In the cases where the subject was unable to respond to the interviewer due to language barrier, the primary caregiver was asked to be a proxy respondent.

\section{Data collection}

Measurement of IADL disability

The IADL questionnaire was used to assess the ability of the respondents to perform eight daily activities, as defined by Lawton \& Brody (1969). These were: ability to use telephone; shopping; prepare meals; perform housekeeping chores; do the laundry; use of public transport; taking medication; and handling finances. Respondents were interviewed to obtain information about their ability to perform these eight daily activities. On the basis of their responses, the respondents were then classified into IADL disability Present or IADL disability Absent. For this study, the presence of IADL disability was defined as the need for help with at least one or more of the eight-item IADL activities (Millán-Calenti et al., 2012). The reliability of IADL used in this study revealed a Cronbach's alpha value of 0.58 .

\section{Socio-demographic characteristics}

A set of questionnaires was used to obtain general socio-demographic information about the respondents, which included gender, age, ethnicity, educational level, marital status, living arrangements, working status, and main economic resource. This information was obtained via face-to-face interviews.
Dietary intake

The amount of food items consumed by the respondents in the past week was recorded by a validated diet history questionnaire (DHQ), via interview, to establish their 'usual' weekly food consumption patterns. The DHQ has the advantage of requiring limited effort by the respondents and should provide detailed information about the food consumed and meal patterns over a longer period, provided that the data are collected by a trained interviewer (Shahar, Earland \& Abdulrahman, 2000). The intake of nutrients (energy and protein) was compared with the Recommended Nutrient Intake (RNI) (NCCFN, 2017).

\section{Social participation}

Two self-reported items on social relation and participation were used to assess the social participation of the respondents:

- Social relations: visited their friends and/or relatives at least once a week with the possible responses of yes or no (Noguiera et al., 2010).

- Social participation: taking part in and/or attending social functions at least once a week with the possible responses of yes or no (Noguiera et al., 2010).

Perceived health status

Two self-rated items were used to assess the perceived health status of the respondents, including:

- Self-rated health: with the possible responses being: poor, neutral, good, and excellent (Nascimento et al., 2012).

- Self-rated health relative to peers: perceived health relative to peers, with the possible responses being poor, neutral, good, and excellent (Nascimento et al., 2012). 
Table 1. Socio-demographic characteristics, dietary intake, social participation, perceived health status and fall risk of respondents $(n=258)$ by gender. Figures in parentheses represent the percentages

\begin{tabular}{|c|c|c|c|}
\hline Characteristics & $\begin{array}{c}\text { Male } \\
(n=123)\end{array}$ & $\begin{array}{l}\text { Female } \\
(n=135)\end{array}$ & $\begin{array}{c}\text { Total } \\
(n=258)\end{array}$ \\
\hline \multicolumn{4}{|l|}{ Age } \\
\hline 60-74 years & $104(84.6)$ & $124(91.9)$ & $228(88.4)$ \\
\hline$\geq 75$ years & $19(15.4)$ & $11(8.1)$ & 30 (11.6) \\
\hline$(M \pm S D)$ & $66 \pm 6.8$ & $65 \pm 6.1$ & $66 \pm 6.5$ \\
\hline \multicolumn{4}{|l|}{ Ethnicity } \\
\hline Malay & $82(66.7)$ & $88(65.2)$ & $170(65.9)$ \\
\hline Chinese & 22 (17.9) & $29(21.5)$ & $51(19.8)$ \\
\hline Indian & 19 (15.4) & $18(13.3)$ & $37(14.3)$ \\
\hline \multicolumn{4}{|l|}{ Educational Level } \\
\hline No formal education & $2(1.6)$ & $13(9.6)^{*}$ & $15(5.8)$ \\
\hline Primary education & 57 (46.3) & $71(52.6)$ & 128 (49.6) \\
\hline Secondary education & $51(41.5)$ & $45(33.3)$ & $96(37.2)$ \\
\hline Tertiary education & $13(10.6)$ & $6(4.4)$ & $19(7.4)$ \\
\hline \multicolumn{4}{|l|}{ Marital status } \\
\hline Single & $6(4.9)$ & $1(0.7)^{*}$ & $7(2.7)$ \\
\hline Married & $108(87.8)$ & $93(68.9)$ & $201(77.9)$ \\
\hline Widowed/Divorced & $9(7.3)$ & $41(30.4)$ & $50(19.4)$ \\
\hline \multicolumn{4}{|l|}{ Living arrangements } \\
\hline Living alone & $4(3.3)$ & $5(3.7)$ & $9(3.5)$ \\
\hline Living with others & $119(96.7)$ & $130(96.3)$ & $249(96.5)$ \\
\hline \multicolumn{4}{|l|}{ Employment } \\
\hline Unemployed & $3(2.4)$ & $63(46.6)^{*}$ & $66(25.6)$ \\
\hline Retired & $68(55.3)$ & $43(31.9)$ & $111(43.0)$ \\
\hline Employed & $52(42.3)$ & $29(21.5)$ & $81(31.4)$ \\
\hline \multicolumn{4}{|l|}{ Income resources } \\
\hline Pension & $48(39.0)$ & $15(11.1)^{*}$ & $63(24.4)$ \\
\hline Salary & $30(24.4)$ & $17(12.6)$ & $47(18.2)$ \\
\hline Children & $23(18.7)$ & $61(45.2)$ & $84(32.6)$ \\
\hline Other (savings, social welfare) & $22(17.9)$ & $42(31.1)$ & $64(24.8)$ \\
\hline \multicolumn{4}{|l|}{ Dietary intake } \\
\hline$<$ RNI energy ${ }^{\dagger}$ & $72(58.5)$ & $91(67.4)$ & $163(63.2)$ \\
\hline Energy intake, kcal $(M \pm S D)$ & $1966 \pm 543$ & $1642 \pm 505^{* *}$ & $1796 \pm 547$ \\
\hline$<$ RNI protein ${ }^{\ddagger}$ & $67(54.5)$ & 70 (51.9) & $137(53.1)$ \\
\hline Protein intake, g $(M \pm S D)$ & $57.99 \pm 16.73$ & $50.00 \pm 16.41^{* *}$ & $53.81 \pm 17.01$ \\
\hline \multicolumn{4}{|l|}{ Visiting friends and/or relatives } \\
\hline Yes & $117(95.1)$ & $115(85.2)^{*}$ & $232(89.9)$ \\
\hline No & $6(4.9)$ & $20(14.8)$ & $26(10.1)$ \\
\hline \multicolumn{4}{|c|}{ Participation in activity/social programs } \\
\hline Yes & $85(69.1)$ & $62(45.9)^{*}$ & $147(57.0)$ \\
\hline No & $38(30.9)$ & $73(54.1)$ & $111(43.0)$ \\
\hline \multicolumn{4}{|l|}{ Perceived of own health status } \\
\hline Excellent/Good & $111(90.2)$ & $115(85.2)$ & 226 (87.6) \\
\hline Neutral/Poor & $12(9.8)$ & $20(14.8)$ & $32(12.4)$ \\
\hline \multicolumn{4}{|l|}{ Perceived health in relation to peers } \\
\hline Excellent/Good & $116(94.3)$ & $126(93.3)$ & $242(93.8)$ \\
\hline Neutral/Poor & $7(5.7)$ & $9(6.7)$ & $16(6.2)$ \\
\hline
\end{tabular}




\begin{tabular}{lccc}
\hline \multirow{2}{*}{ Characteristics } & Male & Female & Total \\
\cline { 2 - 3 } & $(n=123)$ & $(n=135)$ & \\
\hline Fall risk & & & \\
$\quad$ Low $(0-8)$ & $105(85.4)$ & $93(68.9)^{*}$ & $198(76.7)$ \\
$\quad$ Medium $(9-10)$ & $7(5.7)$ & $17(12.6)$ & $24(9.3)$ \\
High $(11-21)$ & $11(8.9)$ & $25(18.5)$ & $36(14.0)$ \\
$\quad$ FRI-21 score $(M \pm S D)$ & $5.98 \pm 2.98$ & $7.47 \pm 3.10^{* *}$ & $6.76 \pm 3.12$ \\
\hline
\end{tabular}

${ }^{*} p<0.05$, significant difference between gender (chi-squared test); ${ }^{* *} p<0.05$, significant difference between gender (independent $t$-test);

$\dagger<$ RNI energy (Male $<2010 \mathrm{kcal} /$ day; Female $<1780 \mathrm{kcal} /$ day)

${ }^{\ddagger}<$ RNI protein (Male $<59 \mathrm{~g} /$ day; Female $<51 \mathrm{~g} /$ day)

Risk of falls

This study used the validated 21-item Fall Risk Index (FRI-21) questionnaire to assess the risk of falls. This index encompassed physical, cognitive, emotional and social aspects of functioning, as well as environmental factors (Toba et al., 2005). Each item was scored 1, when risk was present and 0 when risk was absent. The sum of all items ranged from 0-21, with higher scores indicating higher risk of falls. A cut-off of 9-10 points is useful for early detection of fall risk (Ishimoto et al., 2012). The reliability of FRI-21 in this study indicated Cronbach's alpha value of 0.67 .

\section{Data analysis}

The Nutritionist Pro ${ }^{\mathrm{TM}}$ Diet Analysis (Axxya Systems, Woodinville, WA, USA) software with the Nutrient Composition of Malaysian Food Database (Tee et al., 1997) was used to analyse the dietary intake of the respondents obtained from the DHQ. In addition to DHQ, data from the questionnaire were analysed using IBM's Statistical Package for the Social Sciences (SPSS) version 25.0. The independent $t$-test was used to test the differences of the mean of variables between gender and age group. The chi-square test was used to determine the significance of association $(p<0.05)$ between IADL disability with demographic data, dietary intake, perceived health status and risk of falls. However, if $\geq 1$ cells had expected frequency of $\leq 5$, then the Fisher's exact test was used instead. Factors which were statistically associated $(p<0.05)$ were analysed using a multivariate binary logistic regression using an enter method to identify the best correlates of IADL disability.

\section{Ethical approval}

This study was approved by the University Research Ethics Committee of the Universiti Putra Malaysia (JKEUPM). Written informed consent was obtained from all participants or their family members prior to data collection.

\section{RESULTS}

Out of the 277 eligible participants, 258 agreed to participate in this study, giving a response rate of $93.1 \%$. The socio-demographic characteristics of the study population are shown in Table 1. The sample had a similar distribution of males (48.0\%) and females (52.0\%). The mean age of the respondents was $66 \pm 6.5$ years, ranging from 60-88 years. Most of the respondents $(88.4 \%)$ were from the younger elderly' group between 60-74 years old and only $11.6 \%$ were from the 'older elderly' group ( $\geq 75$ years old). The respondents comprised representatives of three main ethnic groups in Malaysia: Malays (65.9\%), Chinese $(19.8 \%)$ and 
Table 2. Prevalence of IADL disability of the respondents, $n(\%)$ and $M \pm S D$

\begin{tabular}{lccccccc}
\hline $\begin{array}{l}\text { 8-item IADL } \\
\text { disability }\end{array}$ & $\begin{array}{c}60-74 \\
\text { years old } \\
(n=104)\end{array}$ & $\begin{array}{c}\text { Mears old } \\
(n=19)\end{array}$ & $\begin{array}{c}\text { Subtotal } \\
(n=123)\end{array}$ & $\begin{array}{c}60-74 \\
\text { Years old } \\
(n=124)\end{array}$ & $\begin{array}{c}\text { Years old } \\
(n=11)\end{array}$ & $\begin{array}{c}\text { Subtotal } \\
(n=135)\end{array}$ & $\begin{array}{c}\text { Total } \\
(n=258)\end{array}$ \\
\hline $\begin{array}{l}\text { Present } \\
\text { disability }\end{array}$ & $49(47.1)$ & $17(89.5)^{*}$ & $66(53.7)$ & $73(58.9)$ & $11(100.0)^{*}$ & $84(62.2)$ & $150(58.1)$ \\
$\begin{array}{l}\text { Absent } \\
\text { disability }\end{array}$ & $55(52.9)$ & $2(10.5)$ & $57(46.3)$ & $51(41.1)$ & - & $51(37.8)$ & $108(41.9)$
\end{tabular}

IADL score $7.14 \pm 1.15 \quad 5.47 \pm 1.50 * * 6.88 \pm 1.35 \quad 6.81 \pm 1.25 \quad 4.64 \pm 1.29 * * \quad 6.64 \pm 1.396 .76 \pm 1.37$ $(M \pm S D)$

${ }^{*} p<0.05$, significant difference between age group (chi-squared test)

$* * 00.05$, significant difference between age group (independent $t$-test)

Indians (14.3\%). Most of the respondents lived with others $(96.5 \%)$ and only a few $3.5 \%$ lived alone. The majority of the females (62.2\%) had received only a primary level education or none as against $47.9 \%$ of the men. Fewer women were in employment compared to men $(21.0 \%$ versus $43.2 \%)$ and more were dependent on their children and others for financial resources compared to men (76.3\% versus $36.6 \%)$. Women were also less likely than men to be married (68.9\% versus $87.8 \%$ ).

The mean energy intake of the respondents which were $1966 \pm 543$ $\mathrm{kcal} /$ day and $1642 \pm 505 \mathrm{kcal} /$ day for males and females, respectively did not achieve the Malaysian RNI. The mean intake for protein, being $57.99 \pm 16.73 \mathrm{~g} /$ day and $50.00 \pm 16.41 \mathrm{~g} /$ day for males and females, respectively was also lower than Malaysian RNI. Overall, more than half of the respondents consumed energy $(63.2 \%)$ and protein $(53.1 \%)$ below the RNI level. In regard to social participation, it was found that males were more likely to pay visits and participate in any activities compared to th female participants. Overall, most of the respondents perceived their own health status $(87.6 \%)$ and their health in relation to their peers (93.8\%) as being "excellent/ good". The respondents reported a mean FRI-21 score of $6.76 \pm 3.12$, with females having a significantly higher risk of falls $(7.47 \pm 3.10)$ compared with males (5.98 \pm 2.98$)$. Overall, 23.3\% were identified having at risk of falls, with $31.1 \%$ of them being females, compared with $14.6 \%$ males.

The mean \pm SD for the IADL ability of the respondents was $6.76 \pm 1.37$ (Table 2). It appears, from their lower IADL scores, that females had poorer functional status compared to males although there was no significant difference between the genders. In contrast, the results showed that there was a significant difference in the mean of IADL score between age groups in both genders $(p<0.001)$; respondents from the younger elderly group had higher IADL scores compared to those from the older group. More than half $(58.1 \%)$ of the respondents were unable to execute at least one IADL and this was almost doubled for the older elderly (male $=89.5 \%$; female $=100.0 \%$ ) compared to the younger elderly (male $=47.1 \%$; female $=58.9 \%$ ).

Bivariate analysis showed a significant association between several factors and IADL disability. These factors were: age group, ethnicity, educational level, marital status, employment 
Table 3. Distribution of socio-demographic characteristics, dietary intake, social participation, perceived health status and fall risk by IADL disability, $n(\%)$

\begin{tabular}{|c|c|c|c|c|}
\hline Independent Variables & $\begin{array}{c}\text { Present } \\
\text { IADL Disability } \\
(n=150)\end{array}$ & $\begin{array}{c}\text { Absent } \\
\text { IADL Disability } \\
(n=108)\end{array}$ & $\chi^{2}$ value & p-value \\
\hline \multicolumn{5}{|l|}{ Age group } \\
\hline $60-74$ years old & $122(53.5)$ & $106(46.5)$ & $17.28^{*}$ & 0.000 \\
\hline$\geq 75$ years old & $28(93.3)$ & $2(6.7)$ & & \\
\hline \multicolumn{5}{|l|}{ Gender } \\
\hline Male & $66(53.7)$ & $57(46.3)$ & 1.94 & 0.164 \\
\hline Female & $84(62.2)$ & $51(37.8)$ & & \\
\hline \multicolumn{5}{|l|}{ Ethnicity } \\
\hline Chinese & $22(43.1)$ & $29(56.9)$ & $6.05^{* *}$ & 0.049 \\
\hline Malay & $104(61.2)$ & $66(38.8)$ & & \\
\hline Indian & $24(64.9)$ & $13(35.1)$ & & \\
\hline \multicolumn{5}{|l|}{ Educational Level } \\
\hline Formal education & $137(56.4)$ & $106(43.6)$ & $5.35^{*}$ & 0.028 \\
\hline No formal education & $13(86.7)$ & $2(13.3)$ & & \\
\hline \multicolumn{5}{|l|}{ Marital status } \\
\hline Married & $103(51.2)$ & $98(48.8)$ & $17.78^{* *}$ & 0.000 \\
\hline Single/Widowed/Divorced & 47 (82.5) & $10(17.5)$ & & \\
\hline \multicolumn{5}{|l|}{ Living Arrangements } \\
\hline Living with others & $144(57.8)$ & $105(42.2)$ & 0.28 & 0.738 \\
\hline Living alone & $6(66.7)$ & $3(33.3)$ & & \\
\hline \multicolumn{5}{|l|}{ Employment } \\
\hline Employed & $30(37.0)$ & $51(63.0)$ & $21.60^{* *}$ & 0.000 \\
\hline Unemployed/Retired & $120(67.8)$ & $57(32.2)$ & & \\
\hline \multicolumn{5}{|l|}{ Dietary Intake } \\
\hline >RNI energy (kcal) & $42(44.2)$ & $53(55.8)$ & $11.99 * *$ & 0.000 \\
\hline <RNI Energy (kcal) & $108(66.3)$ & $55(33.7)$ & & \\
\hline$\geq \mathrm{RNI}$ protein $(\mathrm{g})$ & $61(50.4)$ & $60(49.6)$ & $5.59^{* *}$ & 0.018 \\
\hline <RNI protein $(\mathrm{g})$ & $89(65.0)$ & $48(35.0)$ & & \\
\hline \multicolumn{5}{|l|}{ Visiting friends and/or relatives } \\
\hline Yes & $125(53.9)$ & $107(46.1)$ & $17.17^{*}$ & 0.000 \\
\hline No & $25(96.2)$ & $1(3.8)$ & & \\
\hline \multicolumn{5}{|c|}{ Taking part in activity/social programs } \\
\hline Yes & 66 (44.9) & $81(55.1)$ & $24.62^{* *}$ & 0.000 \\
\hline No & $84(75.7)$ & $27(24.3)$ & & \\
\hline \multicolumn{5}{|l|}{ Perception of own health status } \\
\hline Excellent/Good & $123(54.4)$ & $103(45.6)$ & $10.33^{* *}$ & 0.000 \\
\hline Neutral/Poor & $27(84.4)$ & 5 (15.6) & & \\
\hline \multicolumn{5}{|c|}{ Perceived health in relation to peers } \\
\hline Excellent/Good & $136(56.2)$ & $106(43.8)$ & $6.04 *$ & 0.017 \\
\hline Neutral/Poor & $14(87.5)$ & $2(12.5)$ & & \\
\hline \multicolumn{5}{|l|}{ Fall risk } \\
\hline No risk & $99(50.0)$ & $99(50.0)$ & $23.74^{* *}$ & 0.000 \\
\hline At risk & $51(85.0)$ & $9(15.0)$ & & \\
\hline
\end{tabular}

* $p<0.05$, significant difference between age group (Fisher's exact test)

$* * p<0.05$, significant difference between age group (chi-squared test) 
Table 4. Binary logistic regression analysis for factors predicting IADL disability $(n=150)$

\begin{tabular}{|c|c|c|c|}
\hline Variables & $\begin{array}{l}\text { Frequency } \\
(n=150)\end{array}$ & $\begin{array}{c}\text { Adjusted OR } \\
\text { (95\% CI) }\end{array}$ & p-value \\
\hline \multicolumn{4}{|l|}{ Age group } \\
\hline 60-74 years old & 122 & 1.000 & \multirow[t]{2}{*}{$0.020^{*}$} \\
\hline$\geq 75$ years old & 28 & $6.4(1.3,30.8)$ & \\
\hline \multicolumn{4}{|l|}{ Ethnicity } \\
\hline Chinese & 22 & 1.000 & 0.363 \\
\hline Malay & 104 & $1.4(0.7,3.0)$ & 0.315 \\
\hline Indian & 24 & $2.1(0.7,5.8)$ & 0.171 \\
\hline \multicolumn{4}{|l|}{ Educational Level } \\
\hline Formal Education & 137 & 1.000 & \multirow[t]{2}{*}{0.546} \\
\hline No formal education & 13 & $1.8(0.3,10.9)$ & \\
\hline \multicolumn{4}{|l|}{ Marital status } \\
\hline Married & 103 & 1.000 & \multirow[t]{2}{*}{$0.038^{*}$} \\
\hline Single/Widowed/Divorced & 47 & $2.5(1.1,5.9)$ & \\
\hline \multicolumn{4}{|l|}{ Employment } \\
\hline Employed & 30 & 1.000 & \multirow[t]{2}{*}{$0.011^{*}$} \\
\hline Unemployed/Retired & 120 & $2.3(1.2,4.3)$ & \\
\hline \multicolumn{4}{|l|}{ Dietary Intake } \\
\hline$\geq$ RNI Energy (kcal) & 42 & 1.000 & \multirow[t]{3}{*}{0.185} \\
\hline <RNI Energy (kcal) & 108 & $1.5(0.8,2.7)$ & \\
\hline$\geq$ RNI Protein (g) & 61 & 1.00 & \\
\hline <RNI Protein (g) & 89 & $1.1(0.5,2.3)$ & 0.902 \\
\hline \multicolumn{4}{|l|}{ Visiting friends and/or relatives } \\
\hline Yes & 125 & 1.000 & \multirow[t]{2}{*}{0.109} \\
\hline No & 25 & $5.7(0.7,48.0)$ & \\
\hline \multicolumn{4}{|c|}{ Taking part in activity/social programs } \\
\hline Yes & 66 & 1.000 & \multirow[t]{2}{*}{0.062} \\
\hline No & 84 & $1.8(0.3,5.8)$ & \\
\hline \multicolumn{4}{|l|}{ Perceived of own health status } \\
\hline Excellent/Good & 123 & 1.000 & \multirow[t]{2}{*}{0.678} \\
\hline Neutral/Poor & 27 & $1.4(0.3,6.0)$ & \\
\hline \multicolumn{4}{|c|}{ Perceived health in relation to peers } \\
\hline Excellent/Good & 136 & 1.000 & \multirow[t]{2}{*}{0.988} \\
\hline Neutral/Poor & 14 & $1.0(0.1,7.5)$ & \\
\hline \multicolumn{4}{|l|}{ Fall risk } \\
\hline No risk & 99 & 1.000 & \multirow[t]{2}{*}{$0.049 *$} \\
\hline At risk & 51 & $2.5(1.3,6.1)$ & \\
\hline
\end{tabular}

${ }^{*} p<0.05$, represents statistical significance

status, energy and protein intake, social relations, social participation, self-rated health, and fall risk. Detailed findings are shown in Table 3 . The respondents of advanced age group ( $\geq 75$ years), who were unmarried, and unemployed, had energy and protein intakes of less than RNI values were associated with IADL disability. From a multivariate binary logistic regression analysis (Table 4), the significant determinants of IADL disability for this study were found to be advanced age ( $\geq 75$ years old, OR $=6.4$; 95\% CI: 1.3, 30.8), being unmarried (OR=2.5; 95\% CI: 1.1, 5.9), unemployed / retired $(\mathrm{OR}=2.3 ; 95 \% \mathrm{CI}: 1.2,4.3)$, and at risk of falls $(\mathrm{OR}=2.5 ; 95 \% \mathrm{CI}: 1.3,6.1)$. 


\section{DISCUSSION}

This study contributes to the literature on the prevalence of self-reported physical disability using IADL, which is one of important predictors for a good quality of life (Onunkwor et al., 2016). Malaysia is experiencing a dramatic increase in elderly population (Bloom et al., 2010) and studies have highlighted that social support (Feng et al., 2013), sufficient dietary intake, absence of depression and cognitive impairment (Vanoh et al., 2017) are among the contributory factors for a healthy physical functioning of elderly (Sathasivam et al., 2015). Although numerous studies on physical disability have been undertaken worldwide, variations in physical disability assessment (e.g. different instrument and scoring methods) across these studies make any direct comparisons difficult. With this limitation, it is reasonable that this study should only be matched with local studies such as those of Nur' Asyura et al. (2010), Momtaz et al. (2012), and Suzana et al. (2013). This is in addition to only a few foreign studies such as Chalise et al. (2008), Coustasse et al. (2008), Ramsay et al. (2008), and Millán-Calenti et al. (2010) all of which also defined disability as the inability to perform at least one of the IADL items.

In this study, the prevalence of IADL disability among the respondents was $58.1 \%$. This finding is comparable with the previous local study of Nur'Asyura et al. (2010) among community-dwelling elderly in the rural areas of Selangor and the state of Negeri Sembilan (located south of Selangor), where the prevalence of IADL disability among the respondents was about fifty percent (49.8\%). More recently, Suzana and colleagues (2012) reported that almost half of their freeliving respondents (43.0\%) from a Federal Land Development Authority (FELDA) agricultural settlement were found to be physically dependent. In stark contrast to these figures, an earlier local study reported that the prevalence of IADL disability among the free-living elderly was only $13.0 \%$ (Shahar et al., 2007). It was noted, then, that there are different ranges of prevalence for IADL disability among the Malaysian elderly. These findings should be interpreted cautiously since there is the possibility of a different number of IADL items used, sample sizes, and settings of the sample studied.

The prevalence of IADL disability in the results of the present study appears to be higher than that in most other countries. Using the same IADL instrument and scoring method, Coustasse et al. (2008) reported that $12.8 \%$ of the elderly in the United States were disabled in terms of IADL, while a study in Britain reported a $15.0 \%$ rate of IADLs (Ramsay et al., 2008). Interestingly, some Asian countries also reported a similar lower prevalence of IADL disability, in contrast to this study, including Nepal (29.2\%) and Sri Lanka (32.3\%) (Chalise et al., 2008; Malhotra et al., 2010). However, there are several studies which also offer quite similar findings to our study. For instance, studies in Spain and Taiwan reported $53.5 \%$ and $48.1 \%$ respectively (Hsu \& Jhan, 2008; Millán-Calenti et al., 2010). The wide disparity between the ranges of prevalence between the countries might be explained by the fact that IADL is influenced by societal, environmental, and cultural factors, such as readiness to adapt and accepting the "sick role" or learned dependency. The high prevalence of IADL disability in this study could be attributed to two IADL items: the ability to use public transport and shopping for groceries, both of which require the elderly to leave their housing areas. This could be due to other external factors such as the accessibility to own transportation, safety issues and the 
lack of provision of support from their close family members or neighbours. In Malaysia, the prevalence of a deeply rooted traditional family culture makes it incumbent on younger family members to take care of the elderly. Unsurprisingly then, most of the respondents (96.5\%) in this study do not live alone but with others (Hairi et al., 2010). It may be concluded that Malaysian elderly tend, as a rule, to be dependent on others or at least are ready to seek assistance. It is also possible that though they claimed to be unable to perform such daily tasks, they were, in fact, not usually allowed to do so by those around them.

The different prevalence rates of IADL disability in these studies is most likely due to the different physical disability scales, items, and scoring methods, that were used. However, the general findings regarding predictors of disability were quite similar. Many studies have shown the significant predictors of IADL disability are old age, being unmarried, unemployment, and at risk of falls (Coustasse et al., 2008; Hsu \& Jhan, 2008; Hairi et al., 2010; Lund, Nilsson \& Avlund, 2010; d'Orsi, Xavier \& Ramos, 2011; Ishimoto et al., 2012; Nascimento et al., 2012). The present study confirms the majority of the predictors that were reported and extends their findings.

In this study, age was found to be a significant risk factor for IADL disability; with increasing age, the odds of reporting disability also increased. Typically, older people are more fragile, are highly susceptible to chronic diseases, and usually after their 70's show a greater loss of muscle mass which would result in difficulties in performing routine activities (Danielewicz, Barbosa \& Del Duca, 2014). The importance of marriage as a factor influencing daily activities was also observed among respondents in this study. It is reasonable to assume that marriage might influence one's overall health status through the social support provided by the spouse, and thereby have a preventative effect on functional disability among elderly people (Pandey, 2011; Chao et al., 2013). Marriage is one of the central sources of social support, and greater social interaction may encourage the elderly to remain physically active, and thus decrease their risk of developing disabilities (Hays et al., 2001).

In this study, being unemployed when elderly was a significant predictor of disability in terms of IADLs. Being unemployed is often associated with low income and poverty, which might lead to a lower standard of living, an unhealthy lifestyle and diet, less frequent use of healthcare services, which may therefore promote a higher risk of diseases (Hairi et al., 2010). The working environment provides a form of social support and interaction with colleagues, which in turn keep the working elderly active and help maintain their functional status (d'Orsi et al., 2011). Thus, it was unsurprising that a study among the Indian elderly found that the likelihood of disability among economically disadvantaged elderly people was higher than those having average to above average incomes (Pandey, 2011). In this study, being at risk of falls was shown to strongly increase the risk of IADL disability among the respondents. As would be expected, post-fall injury or fracture might result in a loss of confidence and reduce activity levels, leading to functional decline. At present, there is still a lack of knowledge about the possible association between fall risk and IADL disability and this is an area for further research.

This study had some limitations. Firstly, the study design was crosssectional, consequently only showing descriptive relationships, and no conclusions on causality could be drawn. Then, the methodology that used was limited to self-reported questionnaires, 
which might lead to under- or overreporting. Misclassification bias can be expected making it more difficult to detect if real associations are present. A performance-based physical disability assessment is recommended for future studies to determine the magnitude of the physical disability. Therefore, cause and effect relationships as well as the magnitude of the contributions of some associations that have been reported need to be further investigated with larger sample sizes using longitudinal, randomised, controlled study design, in various populations across the region.

\section{CONCLUSION}

This study reported a substantial prevalence of IADL disability among the elderly respondents, consistent with the predictors of IADL disability found in some previous studies. It can be strongly concluded, that predictors such as marriage and employment highlight the importance of social support for the elderly, in the Malaysian context. From a wider perspective, the importance of caregivers, family members, and community for providing their support physically and emotionally is necessary if the functional status of the elderly is to be improved.

\section{Acknowledgements}

The researchers are grateful to the elderly subjects, caregivers, field workers and others involved in this study.

\section{Authors' contributions}

MFM, conceptualised and designed the study, led the data collection and prepared the draft of the manuscript; ZI, conceptualised and designed the study, provided advice on the data analysis and its interpretation, and reviewed the manuscript; SNAA, provided advice on the data analysis and interpretation, and reviewed the manuscript; CYM provided advice on the data analysis, interpretation of the findings and reviewed the manuscript.

\section{Conflict of interest}

None of the authors declared a conflict of interest.

\section{References}

Bloom D, Canning D \& Finlay J (2010). Population aging and economic growth in Asia. Econ Consequences Demogr Chang East Asia 19(8):61-89.

Chalise HN, Saito T \& Kai I (2008). Functional disability in activities of daily living and instrumental activities of daily living among Nepalese Newar elderly. Public Health 122(4):394-396.

Chao J, Li Y, Xu H, Yu Q, Wang Y \& Liu P (2013). Health status and associated factors among the community-dwelling elderly in China. Arch Gerontol Geriatr 56(1):199-204.

Coustasse A, Bae S, Arvidson CJ \& Singh KP (2008). Disparities in self-reported activities of daily living and instrumental activities of daily living disability among Asian American subgroups in the United States: Results from the National Health Interview Survey 20012003. Disability and Health Journal 1(3):150156.

Danielewicz AL, Barbosa AR \& Del Duca GF (2014). Nutritional status, physical performance and functional capacity in an elderly population in southern Brazil. Rev Assoc Med Bras 60(3):242-248.

den Ouden MEM, Schuurmans MJ, Brand JS, Arts IEMA, Mueller-Schotte S \& van der Schouw YT (2013). Physical functioning is related to both an impaired physical ability and ADL disability: a ten year follow-up study in middle-aged and older persons. Maturitas 74(1):89-94.

d'Orsi E, Xavier AJ \& Ramos LR (2011). Work, social support and leisure protect the elderly from functional loss: EPIDOSO study. Rev Saude Publica 45:685-692.

Feng Q, Zhen Z, Gu D, Wu B, Duncan PW \& Purser JL (2013). Trends in ADL and IADL disability in community-dwelling older adults in Shanghai, China, 1998-2008. The journals of gerontology. Series B, Psychological sciences and social sciences, 68(3):476-485. doi:10.1093/geronb/ gbt012.

Hairi NN, Bulgiba A, Cumming RG, Naganathan V \& Mudla I (2010). Prevalence and correlates of physical disability and functional limitation among community dwelling older people in rural Malaysia, a middle income country. BMC Public Health 10(1):492.

Hays JC, Steffens DC, Flint EP, Bosworth HB \& George LK (2001). Does social support buffer functional decline in elderly patients with unipolar depression? Am $J$ Psychiatry 158(11):1850-1855. 
Hsu H \& Jhan LJ (2008). Risk factors of falling among the elderly in Taiwan: a longitudinal study. Taiwan Geriatrics Gerontology 3(2):141154.

Ishimoto Y, Wada T, Kasahara Y, Kimura Y, Fukutomi E, Chen W, Hirosaki M, Nakatsuka M, Fujisawa M, Sakamoto R, Ishine M, Okumiya K, Otsuka K \& Matsubayashi K (2012). Fall Risk Index predicts functional decline regardless of fall experiences among community-dwelling elderly. Geriatr Gerontol Int 12(4):659-666.

Lawton MP \& Brody EM (1969). Assessment of older people: self-maintaining and instrumental activities of daily living. Gerontologist 9(3):179186.

Lund R, Nilsson CJ \& Avlund K (2010). Can the higher risk of disability onset among older people who live alone be alleviated by strong social relations? A longitudinal study of non-disabled men and women. Age Ageing 39(3):319-326.

Malhotra R, Chan A \& Ostbye T (2010). Prevalence and correlates of clinically significant depressive symptoms among elderly people in Sri Lanka: findings from a national survey. Int Psychogeriatr 22(2):227-236.

Millán-Calenti JC, Tubío J, Pita-Fernández S, González-Abraldes I, Lorenzo T, FernándezArruty T \& Maseda A (2010). Prevalence of functional disability in activities of daily living (ADL), instrumental activities of daily living (IADL) and associated factors, as predictors of morbidity and mortality. Arch Gerontol Geriatr 50(3):306-310.

Millán-Calenti JC, Tubío J, Pita-Fernández S, Rochette S, Lorenzo T \& Maseda A (2012). Cognitive impairment as predictor of functional dependence in an elderly sample. Arch Gerontol Geriatr 54(1):197-201.

Momtaz YA, Hamid TA \& Ibrahim R (2012). Unmet needs among disabled elderly Malaysians. Soc Sci Med 75(5):859-863.

Nascimento C de M, Ribeiro AQ, Cotta RMM, Acurcio Fde A, Peixoto SV, Priore SE \& Franceschini Sdo C (2012). Factors associated with functional ability in Brazilian elderly. Arch Gerontol Geriatr 54(2):e89-e94.

NCCFN (2017). Recommended Nutrient Intakes for Malaysia. A Report of the Technical Working Group on Nutritional Guidelines. National Coordinating Committee on Food and Nutrition, Ministry of Health, Putrajaya.
Nogueira SL, Ribeiro RCL, Rosado LEFPL, Franceschini SCC, Ribeiro AQ \& Pereira ET (2010). Fatores determinantes da capacidade funcional em idosos longevos. Brazilian $J$ Phys Ther 14(4):322-329.

Nur'Asyura Adznam S, Shahar S, Rahman SA, Yusof NA, Arshad F, Yassin Z, Salleh M, Samah AA \& Sakian NI (2010). An action research on promotion of healthy ageing and risk reduction of chronic disease: A need assessment study among rural elderly Malays, care givers and health professionals. $J$ Nutr Health Aging 13(10):925-930.

Onunkwor OF, Al-Dubai SAR, George PP, Arokiasamy J, Yadav H, Barua A \& Shuaibu HO (2016). A cross-sectional study on quality of life among the elderly in non-governmental organizations' elderly homes in Kuala Lumpur. Health and quality of life outcomes 14:6-6. doi:10.1186/s12955-016-0408-8.

Pandey MK (2011). Poverty and disability among Indian elderly: evidence from household survey. J Disabil Policy Stud 23(1):39-49.

Ramsay SE, Whincup PH, Morris RW, Lennon LT \& Wannamethee SG (2008). Extent of social inequalities in disability in the elderly: results from a population-based study of British men. Ann Epidemiol 18(12):896-903.

Sathasivam J, Kamaruzzaman SB, Hairi F, Ng CW \& Chinna K (2015). Frail elders in an urban district setting in Malaysia: multidimensional frailty and its correlates. Asia Public Journal of Public Health 27(8_suppl):52S-61S. doi: $10.1177 / 1010539515583332$.

Shahar S, Earland J \& Abdulrahman S (2000). Validation of a dietary history questionnaire against a 7-D Weighed record for estimating nutrient intake among rural elderly Malays. Malays J Nutr 6(1):33-44.

Shahar S, Ibrahim Z, Fatah ARA, Rahman SA, Yusoff NA, Arshad F, Yassin Z \& Adznam SN (2007). A multidimensional assessment of nutritional and health status of rural elderly Malays. Asia Pac J Clin Nutr 16(2):346-353.

Suzana S, Kee CC, Jamaludin AR, Noor Safiza MN, Khor GL, Jamaiyah H, Geeta A, Ahmad Ali Z, Rahmah R, Ruzita AT \& Ahmad Fauzi $Y$ (2012). The Third National Health and Morbidity Survey: prevalence of obesity, and abdominal obesity among the Malaysian elderly population. Asia Pac J Public Health 24(2):318-29. 
Suzana S, Boon PC, Chan PP \& Normah CD (2013). Malnutrition risk and its association with appetite, functional and psychosocial status among elderly Malays in an agricultural settlement. Malays J Nutr 19(1):65-75.

Tee ES, Ismail MN, Nasir MA \& Khatijah I (1997). Nutrient Composition of Malaysian Foods. 4th Ed. Malaysian Food Composition Database Programme, Institute for Medical Research, Kuala Lumpur.

Toba K, Okochi J, Takahashi T, Matsubayashi K, Nishinaga M, Yamada S, Takahashi R, Nishijima R, Kobayashi Y, Machida A, Akishita M \& Sasaki H (2005). Development of a portable fall risk index for elderly people living in the community. Nippon Ronen Igakkai Zasshi Japanese J Geriatr 42(3):346-352.
Vanoh D, Shahar S, Din NC, Omar A, Vyrn CA, Razali R, Ibrahim R \& Hamid TA (2017). Predictors of poor cognitive status among older Malaysian adults: baseline findings from the LRGS TUA cohort study. Aging Clinical Experimental Research 29(2):173-182. doi:10.1007/s40520-016-0553-2.

Zisberg A, Shadmi E, Gur-Yaish N, Tonkikh O \& Sinoff G (2015). Hospital-associated functional decline: the role of hospitalization processes beyond individual risk factors. J Am Geriatr Soc 63(1):55-62. 